\title{
Inventarisasi Jenis-jenis Ular ( Serpenthes ) di Kawasan Universitas Tanjungpura Pontianak.
}

\author{
Rambosius $^{1}$, Tri Rima Setyawati ${ }^{1}$, Riyandi $^{1}$ \\ ${ }^{1}$ Program Studi Biologi, Fakultas MIPA, Universitas Tanjungpura, Jl. Prof. Dr. H. Hadari Nawawi, Pontianak \\ email korespondensi: rambosius92@gmail.com
}

\begin{abstract}
Snakes is a Reptilian that important role in the food chains. This research was conducted in the area of Tanjungpura University, Pontianak. The aim of this research use to determine the types of snakes found and to find out the characteristics of each snake types in Tanjungpura University area Pontianak. The sampling research was done from March to May 2018, with the Visual Encounter Survey (VES) method. The results found 17 individual of 10 species, 7 families (Colubridae, Cylindrophiidae, Elapidae, Homalopsidae, Pythonidae, Typhlopidae, and Xenopeltidae). The snakes found consisted of 7 species of non- venomous snakes which included as Coelognathus flavolineatus, Cylindrophis ruffus, Homalopsis bucatta, Malayophiton reticulatus, Ptyas korros, Ramphotyphlops braminus (free-living snakes), Xenopeltis unicolor, and 3 species of poisonous snakes which included as Ahaetulla prasina, Dendrelaphis pictus, and Naja sputatrix.
\end{abstract}

Keywords: Inventory, Serpenthes, Snake.

\section{PENDAHULUAN}

Ular merupakan kelompok hewan Reptil melata yang tidak mempunyai tungkai, memiliki sisik di seluruh tubuhnya, dan memiliki tubuh yang ramping memanjang. Ular termasuk salah satu satwa yang berperan penting dalam rangkaian alur rantai makanan. Taylor dan O'shea (2004), menyebutkan bahwa jumlah jenis ular di seluruh dunia mencapai 2.700 jenis, 250 jenis diantaranya terdapat di Indonesia, dan 154 jenis dari 10 famili sudah ditemukan di Pulau Kalimantan (Stuebing dan Inger, 1999 dalam Purbatrasila 2009). Purbatrapsila (2009) lebih lanjut menyebutkan bahwa terdapat 14 jenis ular di Taman Nasional Tanjung Puting, Kalimantan Tengah. Wiguna et al., (2009) mendapatkan 6 jenis ular di Desa Keliling Benteng Ilir Kecamatan Sungai Tabuk Kabupaten Banjar.

Kawasan Universitas Tanjungpura (UNTAN) Pontianak merupakan kawasan tempat aktivitas perkuliahan. Kawasan ini selalu dilalui oleh mahasiswa maupun masyarakat setempat. Kampus UNTAN sebagian masih memiliki hutan yang banyak terdapat pepohonan besar, selain itu area kampus UNTAN juga terdapat persawahan, perkebunan, dan area terbuka hijau. Asad et al., (2012) menyebutkan bahwa keberadaan ular dapat ditemukan di atas pepohonan, bawah pohon yang sudah mati, parit aliran air, semak-semak, serasah, dan di lubang tanah.

Adapun tujuan penelitian ini adalah untuk mengetahui jenis-jenis ular yang terdapat di
Kawasan Universitas Tanjungpura Pontianak dan Mengetahui karakteristik jenis ular di Kawasan Universitas Tanjungpura Pontianak

\section{BAHAN DAN METODE}

Penelitian ini berlangsung selama 3 (tiga) bulan, mulai dari Maret-Mei 2018. Pengambilan sampel dilakukan di kawasan Universitas Tanjungpura Pontianak selama satu bulan. Sampel diambil mulai pukul 06.00-11.00 WIB, kemudian dilanjutkan lagi pada malam hari pukul 19.0023.00. Identifikasi ular pengolahan data dilakukan di Laboratorium Zoologi Fakultas Matematika dan Ilmu Pengetahuan Alam, Universitas Tanjungpura, Pontianak

Universitas Tanjungpura Pontianak terdapat di Kecamatan Pontianak Tenggara. Area di sekitar Universitas Tanjungpura merupakan hutan sekunder, tersier, semak-semak dan kawasan terbuka. Topografi di daerah ini berupa tanah datar dengan rawa gambut dangkal. Jenis tanah di daerah ini adalah tanah organosol dan aluvial.

Alat yang digunakan untuk pengambilan sampel di lapangan adalah headlamp, Global Position System (GPS map 60cs), kamera, kantung pesimen (karung), rol meter (ukuran $500 \mathrm{~cm}$ ), senter, stik kayu, stik grab, termohygrometer dan spuit. Alat yang digunakan untuk identifikasi di Laboratorium adalah jangka sorong (kaliper) dan buku identifikasi. Bahan yang digunakan dalam 
penelitian ini adalah spiritus, kertas tisu, formalin $10 \%$, alkohol $70 \%$ dan kloroform.

Penelitian ini dilaksanakan dengan menggunakan metode observasi yang di bagi menjadi observasi pagi dan malam. Metode pengambilan sampel dilakukan dengan metode Visual Encountered Survey (VES) atau metode yang terlihat secara langsung objeknya di sepanjang lokasi jelajah (Kusrini, 2008).

Pengambilan sampel dilakukan dengan cara penangkapan langsung menggunakan tongkat ular. Pencarian dan penangkapan ular dilakukan di beberapa tempat seperti aliran air parit, rawa, hutan, areal perkebunan, persawahan, dan ruang terbuka hijau. Ular yang ditemukan dimasukan kedalam kantong spesimen dan diberi kertas label yang telah diberi nomor penangkapan. Pengambilan sampel dilakukan pengulangan sebanyak dua kali yaitu pagi dan malam selama satu bulan. Bersamaan dengan penangkapan sampel, diamati dan dicatat rona lingkungan yang berkaitan dengan vegetasi dan keadaan lingkungan serta diukur paremeter lingkungan seperti kelembaban, titik koordinat, dan suhu udara, waktu, dan kondisi cuaca sebagai data tambahan untuk analisis habitat satwa (Krey, 2008).

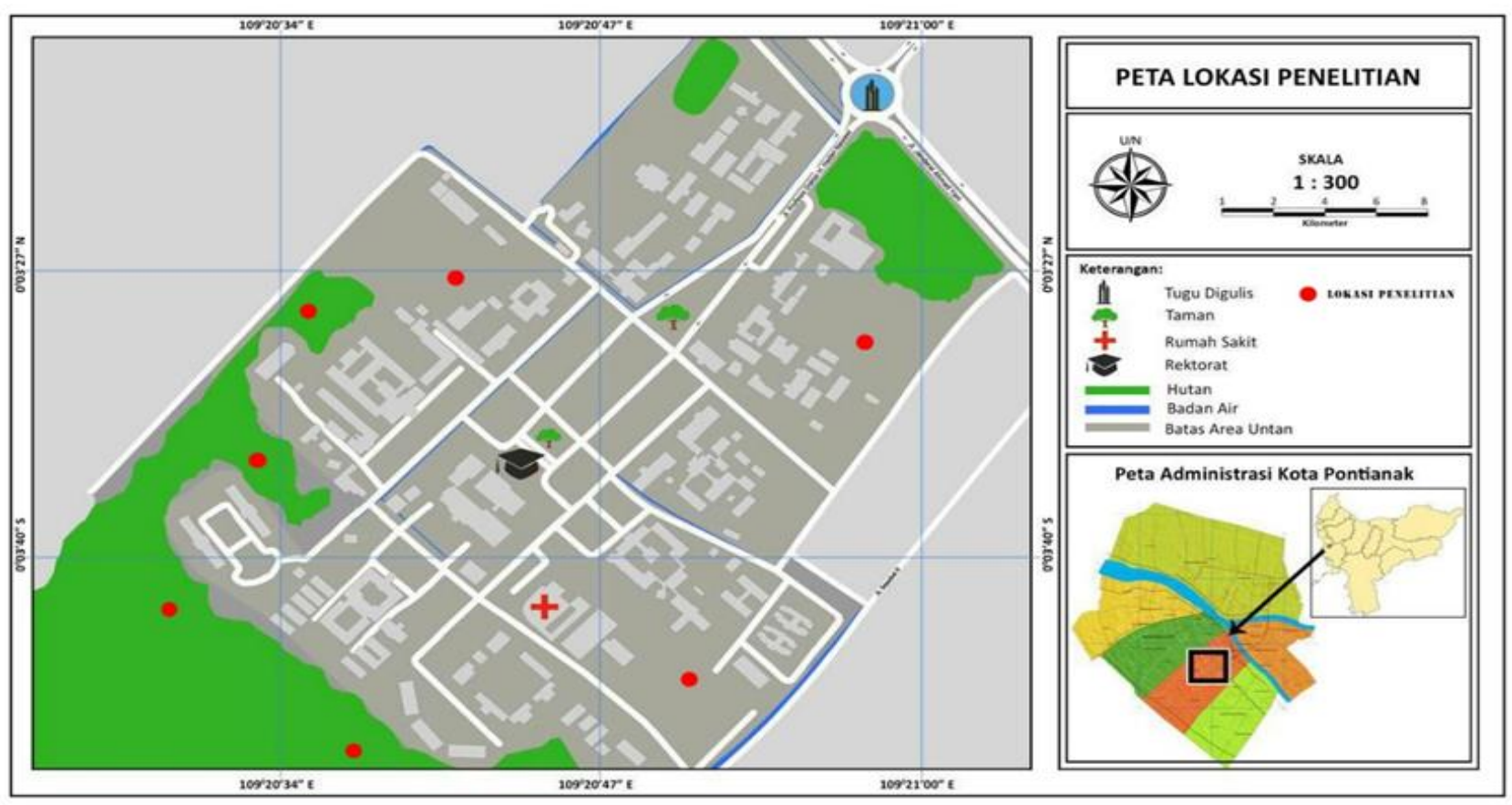

Gambar 1. Peta Lokasi Penelitian (Peta Template Mapsoure Garmin, 2017)

\section{HASIL}

\section{Komposisi Jenis-jenis Ular yang Ditemukan di Kawasan UNTAN}

Berdasarkan hasil penelitian yang telah dilakukan, diketahui bahwa di kawasan Kampus Universitas Tanjungpura Pontianak ditemukan 17 individu dari 10 spesies yang masuk dalam 7 famili yang terdiri atas Colubridae, Cylindrophiidae, Elapidae, Homalopsidae, Pythonidae, Typhlopidae dan Xenopeltidae (Tabel 1).
Sepuluh jenis ular yang ditemukan di sekitar kawasan Kampus Universitas Tanjungpura Pontianak terdiri atas 7 ular tidak berbisa yang meliputi $C$. flavolineatus, $C$. ruffus, $H$. buccata, $M$. reticulatus, $P$. korros, $R$. braminus (ular yang lepas), dan X. Unicolor (Gambar 1). Spesies ular $R$. braminus yang ditemukan lepas dan belum sempat didokumentasi dan diukur morfometri serta meristiknya. Tiga jenis ularberbisa yang ditemukan di kawasan UNTAN meliputi Ahaetulla prasina, Dendrelaphis pictus, dan Naja sputatrix (Gambar 2). 
Protobiont (2019) Vol. 8 (2) : 35 - 46

Tabel 1. Jenis-jenis Ular yang Ditemukan di Kawasan Kampus Universitas Tanjungpura Pontianak

\begin{tabular}{|c|c|c|c|c|c|c|c|c|c|c|}
\hline \multirow{2}{*}{ Spesies } & \multirow{2}{*}{ Nama lokal } & \multicolumn{7}{|c|}{ Lokasi } & \multirow{2}{*}{ Total } & \multirow{2}{*}{$\begin{array}{c}\text { Berbisa } \\
(\sqrt{ })\end{array}$} \\
\hline & & 1 & 2 & 3 & 4 & 5 & 6 & 7 & & \\
\hline \multicolumn{11}{|l|}{ Colubridae: } \\
\hline Ahaetulla prasina & Ular Pucuk & - & - & - & - & - & 1 & - & $1 *$ & $\sqrt{ }$ \\
\hline Coelognathus & Ular Kopi & - & - & 1 & - & - & - & - & $1 *$ & - \\
\hline flavolineatus & Ular Lidi & 1 & - & - & 1 & - & 1 & 1 & $4 * *$ & - \\
\hline $\begin{array}{l}\text { Dendrelaphis pictus } \\
\text { Ptyas korros }\end{array}$ & Ular Tikus & - & - & - & - & - & - & 1 & $1^{*}$ & $\sqrt{ }$ \\
\hline $\begin{array}{l}\text { Cylindrophiidae: } \\
\text { Cylindrophis ruffus } \\
\text { Elapidae: }\end{array}$ & Ular Kepala dua & - & - & 2 & - & - & 1 & - & 3 & - \\
\hline $\begin{array}{l}\text { Naja sputatrix } \\
\text { Homalopsidae: }\end{array}$ & Ular Tedung & - & 1 & 1 & - & - & - & - & 2 & $\sqrt{ }$ \\
\hline $\begin{array}{l}\text { Homalopsis buccata } \\
\text { Pythonidae: }\end{array}$ & Ular Kadut air & - & - & 1 & - & - & - & - & $1 *$ & - \\
\hline $\begin{array}{l}\text { Malayophiton } \\
\text { reticulatus }\end{array}$ & Ular Sanca batik & - & - & - & - & 1 & - & 1 & 2 & - \\
\hline $\begin{array}{l}\text { Typhlopidae: } \\
\text { Ramphotyphlops } \\
\text { braminus }\end{array}$ & Ular Kawat & - & - & - & - & - & 1 & - & $1 *$ & - \\
\hline Xenopeltidae: & & & & & & & & & & \\
\hline Xenopeltis unicolor & Ular Pelangi & - & - & - & 1 & - & - & - & $1 *$ & - \\
\hline$\sum$ Taksa & & 1 & 1 & 4 & 2 & 1 & 4 & 3 & 17 & 3 \\
\hline
\end{tabular}

Keterangan: (*) Paling sedikit, (**) Paling Banyak, (1) Kampus FKIP, (2) Kampus Ekonomi dan Kehutanan baru, (3) Kampus Kedokteran dan Kampus Hukum, (4) Kampus Fisip dan Kampus Pertanian, (5) Kampus Teknik, (6) Kampus MIPA, (7) Kampus Kehutanan Lama
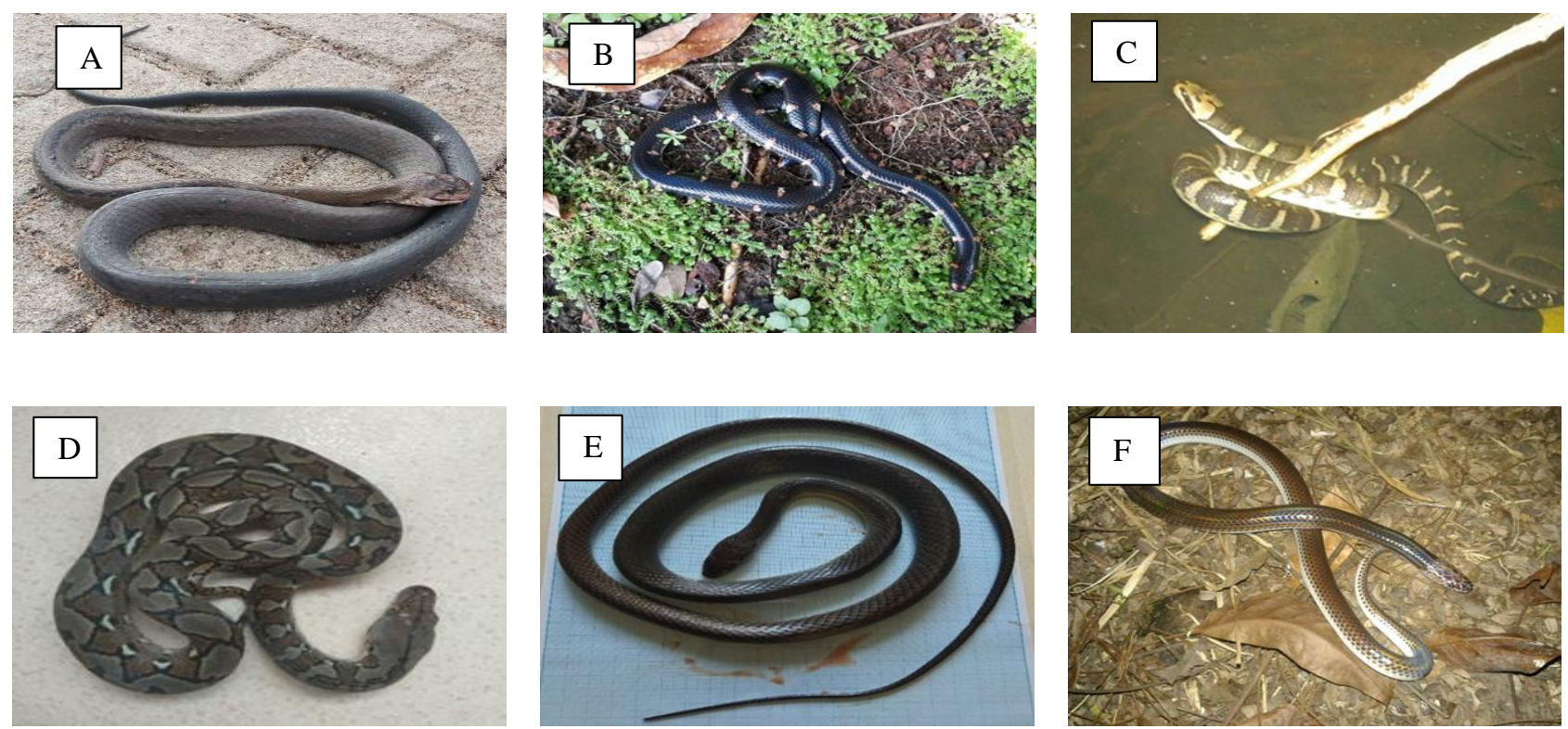

Gambar 2: Jenis ular yang tidak berbisa ditemukan di sekitar Kawasan Kampus Universitas Tanjungpura Pontianak terdiri dari ular (A) C. flavolineatus, (B) C. ruffus, (C) H. buccata, (D) M. reticulatus, (E) P. korros, (F) X. unicolor. 

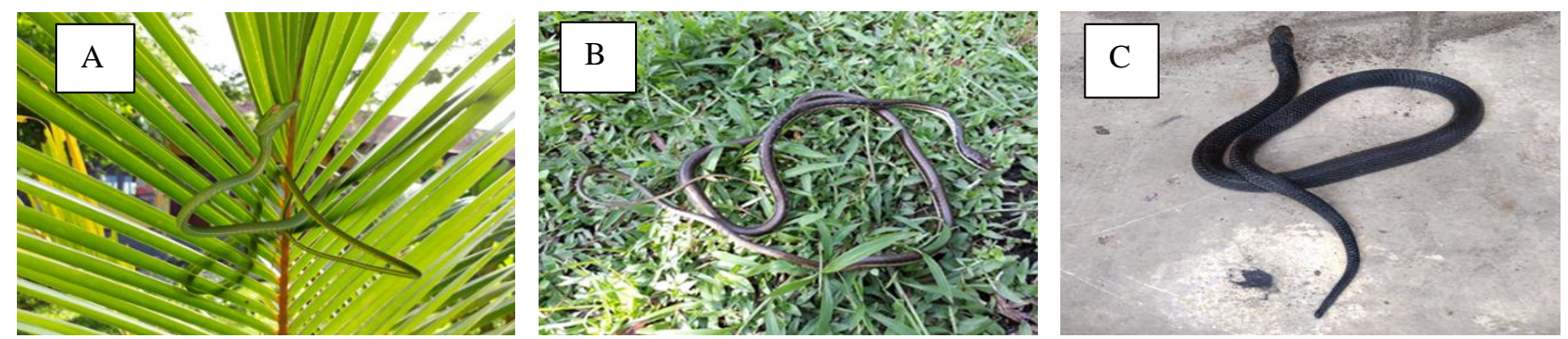

Gambar 3: Jenis ular berbisa yang ditemukan di sekitar Kawasan Kampus Universitas Tanjungpura Pontianak terdiri dari ular (A) A. prasina (bebisa lemah), (B) D. pictus (berbisa bagi sesama ular), dan (C) N. sputatrix (berbisa mematikan).

\section{Morfologi Ular di Kawasan Kampus UNTAN.}

Hasil pengukuran morfometri ular yang ditemukan di Kawasan Kampus UNTAN Pontianak memiliki panjang total berkisar 410-1.54 $\mathrm{mm}$, dengan panjang ekor 7-485 mm. Ular yang paling panjang adalah ular C. flavolineatus atau ular kopi dan ular terpendek adalah ular $C$. ruffus atau ular kepala dua.

Tabel 2. Karakter Morfometri Ular yang ditemukan di Kawasan Kampus UNTAN Pontianak.

\begin{tabular}{|c|c|c|c|c|c|c|}
\hline \multirow[b]{2}{*}{ Spesies } & \multicolumn{6}{|c|}{ Morfometri } \\
\hline & $\begin{array}{c}\text { PT } \\
(\mathrm{mm})\end{array}$ & $\begin{array}{c}\mathrm{PE} \\
(\mathrm{mm})\end{array}$ & $\begin{array}{c}\text { PK } \\
(\mathrm{mm})\end{array}$ & $\begin{array}{c}\text { LK } \\
(\mathrm{mm}) \\
\end{array}$ & $\begin{array}{l}\text { JMH } \\
(\mathrm{mm})\end{array}$ & $\begin{array}{l}\text { JAM } \\
(\mathrm{mm})\end{array}$ \\
\hline $\begin{array}{l}\text { Ahaetulla } \\
\text { prasina }\end{array}$ & 990 & 330 & 25.96 & 9.02 & 5.11 & 7.94 \\
\hline $\begin{array}{l}\text { Coelognathus } \\
\text { flavolineatus }\end{array}$ & 1540 & 345 & 30.12 & 22.74 & 11.05 & 11.00 \\
\hline $\begin{array}{l}\text { Cylindrophis } \\
\text { ruffus }\end{array}$ & $410-570$ & $7-20$ & $114-159$ & 977- 10.11 & $3-3.6$ & $5-5.7$ \\
\hline $\begin{array}{l}\text { Dendrelaphis } \\
\quad \text { pictus }\end{array}$ & $735-990$ & $220-320$ & $17.11-28.33$ & $7.78-15.10$ & $5.00-7.22$ & $1.11-13.10$ \\
\hline $\begin{array}{l}\text { Homalopsis } \\
\text { buccata }\end{array}$ & 580 & 150 & 2.395 & 15.2 & 6.82 & 9.82 \\
\hline $\begin{array}{c}\text { Malayophiton } \\
\text { reticulatus }\end{array}$ & $710-820$ & $91-120$ & $35.00-40.00$ & $14.35-19.79$ & $11.77-13.44$ & $12.00-13.47$ \\
\hline Naja sputatrix & 900 & 105 & 25.00 & 18.13 & 18.00 & 15.00 \\
\hline Ptyas korros & 1300 & 485 & 30.10 & 20.11 & 10.13 & 13.00 \\
\hline $\begin{array}{r}\text { Xenopeltis } \\
\text { unicolor }\end{array}$ & 490 & 58 & 19.47 & 10.98 & 4.87 & 5.70 \\
\hline
\end{tabular}

Keterangan: PT (Panjang Total), PE (Panjang Ekor), PK (Panjang Kepala), LK (Lebar Kepala), JMH (Jarak Mata ke Hidung), JAM (Jarak antar Mata).

Ular yang ditemukan di kawasan Universitas Tanjungpura Pontianak memiliki karaketer meristik yang berbeda dalam jumlah sisik, namun ada juga yang sama. Sepuluh jenis ular yang ditemukan ada beberapa jenis ular yang memiliki jumlah sisik supra labial yang sama, seperti pada jenis ular $A$. prasina, $C$. flavolineatus dan $D$. pictus yang memiliki 9 baris supra labial sementara jenis ular dari P. Korros, X. unicolor memiliki 8 baris supra labial.

ciri karakter meristik dari ular yang ditemukan di kawasan Universitas Tanjungpura Pontianak dapat Tabel 3. Karakter Meristik Ular yang ditemukan di Kawasan Kampus Universitas Tanjungpura Pontianak dilihat pada Tabel 3. Sisik kepala bagian supra labial ular yang ditemukan berjumlah antara 7-21 baris. Sisik supra labial yang paling banyak adalah sisik dari ular M. reticulatus dan sisik supra labial yang paling sedikit adalah sisik dari ular $N$. sputatrix. Sisik infra labial berjumlah 6-13 baris. Sisik infra labial paling banyak terdapat pada ular $H$. bucatta dan $M$. reticulatus. sisik loreal 0-2 baris, sisik melingkar setengah tubuh berjumlah 15-73 baris, sedangkan sisik dari ventral ular berjumlah 0324 baris, dengan tipe ekor ular sebagian besar divided dan satu jenis lainnya single yaitu pada ular C. ruffus. 


\begin{tabular}{|c|c|c|c|c|c|c|c|c|c|c|}
\hline \multirow{2}{*}{ Meristik } & & \multicolumn{9}{|c|}{ Spesies } \\
\hline & & AP & $\mathrm{CF}$ & $\mathrm{CR}$ & DP & $\mathrm{HB}$ & MR & NS & PK & $\mathrm{XU}$ \\
\hline \multirow{5}{*}{ Kepala } & $S L$ & 9 & 9 & 6 & 9 & 12 & 21 & 7 & 8 & 8 \\
\hline & $I L$ & 9 & 9 & 6 & 10 & 13 & 13 & 9 & 10 & 8 \\
\hline & Pre- $O$ & 1 & 2 & 0 & 1 & 2 & 2 & 1 & 2 & 1 \\
\hline & Post-O & 2 & 2 & 1 & 2 & 2 & 4 & 3 & 2 & 2 \\
\hline & Loreal & 2 & 1 & 0 & 1 & 2 & 3 & 0 & 1 & 0 \\
\hline \multirow[t]{2}{*}{ Badan } & $D M B$ & 15 & 19 & 22 & 15 & 39 & 49-73 & 17 & 15 & 15 \\
\hline & $S V$ & 231 & 210 & 0 & 179 & 169 & $221-324$ & 188 & 171 & 182 \\
\hline Ekor & $\begin{array}{l}\text { Singlel } \\
\text { divided }\end{array}$ & Divided & Divided & Single & Divided & Divided & Divided & Divided & Divided & Divided \\
\hline $\begin{array}{l}\text { Keping } \\
\text { anal }\end{array}$ & $\begin{array}{l}\text { Singlel } \\
\text { divided }\end{array}$ & Divided & Single & Divided & Divided & Divided & Single & Single & Divided & Divided \\
\hline
\end{tabular}

Keterangan: AP (A. prasina), CF (C. flavolineatus), CR (C. ruffus), DP (D. pictus), HB (H. bucatta), MR (M. reticulatus), NS (N. sputatrix), PK (P. korros), XU (X. unicolor), SL (Supra labial), IL (Infra labial), Pre-O (Pre ocular), Post-O (Post ocular), DMB (Dorsal at midbody), SV ( Sisik ventral).

\section{Parameter Lingkungan}

Pengukuran parameter lingkungan di kawasan sekitar lingkungan Kampus Universitas Tanjungpura Pontianak dilakukan setiap pagi dan malam selama satu bulan. Parameter lingkungan yang diukur meliputi kelembaban udara dan suhu. Berdasarkan hasil pengukuran suhu dan kelembaban udara yang diambil selama satu bulan di Kawasan Kampus Universitas Tanjungpura Pontianak berkisar $25-33^{\circ} \mathrm{C}$ pada waktu pagi hari, dan malam hari berkisar $24-27^{\circ} \mathrm{C}$, kelembaban udara pada waktu pagi hari berkisar $27-38 \%$ sedangkan pada malam hari berkisar antara 25$45 \%$ (Tabel 4).

Tabel 4. Parameter kelembaban udara dan Suhu udara di kawasan Kampus Universitas Tanjungpura Pontianak.

\begin{tabular}{ccc}
\hline Parameter & Waktu \\
\hline & Pagi (06.00-11.00) & Malam (19.00-23.00) \\
\hline Suhu per minggu $\left({ }^{\circ} \mathrm{C}\right):$ & $28-32$ & $24-29$ \\
1 & $25-29$ & $25-28$ \\
2 & $32-33$ & $34-27$ \\
3 & $27-29$ & $27-28$ \\
4 & & \\
Kelembaban per minggu (\%): & $31-45$ & $31-42$ \\
1 & $29-36$ & $28-29$ \\
2 & $27-43$ & $40-45$ \\
3 & $38-46$ & $25-27$ \\
\hline
\end{tabular}

\section{Pembahasan}

Jenis-jenis ular yang ditemukan di kawasan UNTAN Pontianak, terdiri atas 10 jenis ular. Ular tidak berbisa terdiri atas 7 jenis yaitu $(C$. flavolineatus, C. ruffus, H. buccata, M. reticulatus, P. korros, Ramphotyphlops braminus (ular yang lepas), dan $X$. unicolor), dan hanya tiga jenis ular berbisa yaitu ular A. prasina, D. pictus, N. sputatrix, dan $X$. unicolor termasuk ular bebisa.

Ular C. flavolineatus atau ular kopi, memiliki panjang total $1540 \mathrm{~mm}$ dan panjang ekor $345 \mathrm{~mm}$. Ular C. flavolineatus memiliki sisik setengah lingkaran berjumlah 19 baris, sisik bagian ventral berjumlah 210 baris, sisik kepala bagian supra labial dan infra labial berjumlah 9 baris, anal kloaka ekor divided, sisik ekor (single), bagian preocular dan postocular-nya dua pola, sisiknya berlunas (keeled). Diameter tengah badan mencapai $2.58 \mathrm{~mm}$ dan $1.5 \mathrm{~mm}$ pada bagian ekor. Utiger et al, (2005) menemukan ular C. flavolineatus dengan jumlah sisik supra labial sebanyak 8-9 baris, dengan sisik sisik setengah lingkaran berjumlah 19 dan memiliki tipe single pada anal.

Tubuh ular C. flavolineatus didominasi oleh warna cokelat dan hitam. Anterior berwarna cokelat dan posterior berwarna hitam sampai ke ujung ekor. 
Warna kepala bagian dorsal ular cokelat kehitaman, bibirnya berwarna pucat. Terdapat garis coreng hitam di bawah mata yang berlanjut hingga ke daerah bibir bawahnya. Di bagian belakang mata terdapat garis hitam dari sisik temporal ke arah leher. Kepala bagian ventral berwarna putih kekuningan. Badan bagian dorsal berwarna cokelat makin ke posterior berwarna hitam, dengan garis vertebral berwarna kemerahan yang bagian sisinya hitam. Pada bagian ventro lateral terdapat bintikbintik hitam di kedua sisi dan hanya ada di bagian anterior badan. Bagian ventral ular kopi berwarna putih kekuningan, dari arah anterior menuju ke posterior berwarna hitam. Ekor bagian dorsal ventral hitam sampai ke ujung ekor ular. Untuk ular muda biasanya pada bagian badan anterior mempunyai bentuk lingkaran hitam dengan warna kuning di tengahnya.

Ular C. flavolineatus ini ditemukan pada waktu siang hari di samping Rusunawa UNTAN dekat parit kebun ubi kayu, semak-semak. Subasli (2012), menyebutkan bahwa ular ini ditemukan di kawasan persawahan, ladang, dan hutan dataran rendah. Grismer (2012), juga menyebutkan bahwa ular C. flavolineatus sering dijumpai di daerah hutan terbuka seperti tepi atau sisi jalur, savana, semak belukar, padang rumput, di daerah perkebunan, dan pinggir perkotaan. Pada penelitian ini ular C. flavolineatus ditemukan sedang aktif bergerak mencari makan.

Ular C. ruffus atau ular kepala dua memiliki panjang total $410 \mathrm{~mm}-570 \mathrm{~mm}$, panjang ekor 7 mm- $20 \mathrm{~mm}$, panjang kepala 10.14-15.90 mm dan lebar kepala 9.77 mm- $10.11 \mathrm{~mm}$. Jumlah sisik lingkaran tubuh ular berjumlah 22 baris. Sisik bagian kepala bagian infra labial dan supra labial berjumlah 6 baris.

Tubuh ular $C$. ruffus yang ditemukan didominasi oleh warna hitam dengan pita merah atau putih. Warna ular ini terlihat berbeda-beda tergantung dari cahaya yang memantul. Biasanya ular ini menghasilkan warna sisik yang biru, hijau, kuning, atau merah. Sisik bawah ular memiliki pola kotak-kotak hitam dan putih, kecuali pada ekor. Ekor ular ini berwarna hitam, putih, dan memiliki ujung berwarna merah. Sisik ular ini memiliki pola sisik yang halus, licin, terkadang sisiknya terlihat seperti pelangi ketika terkena cahaya.

Ular $C$. ruffus memiliki mata berwarna hitam sangat kecil. Ular C. ruffus ditemukan di atas tanah, tepi aliran air, parit yang dangkal yang berair, tempat-tempat lembab yang banyak pepohonan. Hasil penelitian ini sama dengan hasil penelitian Wogan (2008), yang menyebutkan bahwa ular ini hidup di habitat basah, terbuka, dataran rendah, termasuk sawah, kebun, sisi jalan parit, kanal, kolam, dan danau. Ular C. ruffus atau ular kepala dua termasuk ular nokturnal, namun biasa juga ditemukan pada pagi hari. Ular ini pemakan cacing, kadang juga ikan-ikan kecil. Ular kepala dua memiliki ukuran sedang dengan tubuh silinder, kepala kecil, bagian moncong tumpul, mata kecil, pupil mata bulat, dengan lubang hidung menusuk di tengah hidung tunggal, sisik atas kepala besar dan simetris, tidak ada loreal dan pre ocular dan ekor sangat pendek tumpul (Amarasinghe et al., 2015).

Ular $H$. buccata atau disebut ular kadut air yang ditemukan memiliki panjang total $580 \mathrm{~mm}$, dengan panjang ekor $150 \mathrm{~mm}$, dan panjang kepala 23.95 $\mathrm{mm}$. Ular ini memiliki sisik bagian kepala bagian supra labial 12 baris, infra labial 13 baris, sisik pre ocular dan post ocular masing-masing memiliki 2 baris, terdapat 2 sisik loreal. Sisik badan ular bagian dorsal ular berjumlah 39 baris, ventral 169 baris. Ekor ular berpola divided. Ular ini termasuk ular yang masih anakan karena ukuran tubuh yang masih kecil. Matisson (2014), menyebutkan bahwa panjang tubuh ular $H$. buccata berkisar $80-110 \mathrm{~cm}$, sedangkan Subasli (2012), menyebutkan bahwa ular dewasa memiliki panjang $100 \mathrm{~cm}$.

Warna kepala bagian dorsal ular berwarna cokelat tua agak terang yang menutupi kepala, sedangkan bagian ventral kepala putih kekuningan ada bintik hitam bagian tepi kepala. Bagian atas moncong ular terlihat persegi tiga berwarna hitam serta terdapat warna belang hitam membujur melalui mata dan berujung ke daerah sudut sehingga menyatu warna cokelat kegelapan di bagian tengkuknya, warna punggung cokelat keabu-abuan. Warna bagian dorsal badan ular kecokelatan keabu-abuan, dengan tepi berwarna hitam, terdapat belang kuning kecokelatan yang melingkar setengah badan melingkar, ventral bagian badan berwarna putih kekuningan ada bintik hitam di tepi yang berurutan. Ekor ular bagian dorsal berwarna hitam belang kecoklatan dan ventral bagian ekor berwarna putih belang-belang hitam sampai ke ujung ekor. Ular ini ditemukan di parit yang terendam air sekitar kurang lebih $10 \mathrm{~cm}$ dan terlihat banyak daun-daunan maupun sampah karena jaraknya dekat dengan tempat pembuangan sampah depan rusun putra atau belakang rusun putri Untan arah samping dalam 
kondisi kepala timbul di atas air dan sedang diam mengapung di permukaan air.

Habitat dari ular H. buccata ini meliputi kawasan daerah persawahan, kolam, dan sungai. Ular $H$. buccata ini ditemukan di parit yang tergenang air dengan kedalaman sekitar $10 \mathrm{~cm}$. Subasli, (2012) menyebutkan bahwa $H$. buccata sering ditemukan di semua jenis air termasuk rawa dan air payau. Ular kadut air juga sering ditemukan di sekitar area lingkungan manusia seperti di bagian selokan dan parit. Ular ini aktif pada malam hari untuk mencari mangsa. Ular kadut air pada penelitian ini ditemukan pada malam hari pukul 21.15 WIB dengan kondisi cuaca cerah. Menurut Wicaksono et al. (2015), ular H. buccata ditemukan pada waktu malam hari pukul 20.30 WIB. Mangsa dari ular $H$. buccata ini yaitu katak, dan ikan, sehingga menjadi hama bagi ikan-ikan yang dipelihara di kolam. Pada siang hari ular ini berada di dalam tanah. Ular $H$. buccata termasuk ular yang berbisa kecil memiliki bentuk kepala segitiga lebar, mata kecil, dengan tubuh gempal. Ular ini memiliki taring bisa yang sangat kecil yang terletak di bagian depan dan belakang rahang atas. Ular tidak mengigit jika dipegang dan tidak bahaya bagi manusia (Mattison, 2014). Ular ini akan agresif jika kondisi terganggu (Forey dan Fitzsimons, 1987).

Ular $M$. reticulatus memiliki panjang total tubuh 710-820 mm, panjang ekor 91-120 mm, panjang kepala 35.00-40.00 mm dan lebar 14.35-19.79 mm. Kepala ular sawah batik memiliki sisik supra labial berjumlah 21 keping, infra labial berjumlah 13 keping, pada sisik bagian depan mata atau pre ocular berjumlah 2 keping, sedangkan sisik bagian belakang mata atau post ocular berjumlah 4 keping. Ular ini juga memiliki 3 keping sisik loreal. Ular sawah batik yang ditemukan memiliki sisik setengah lingkaran berjumlah 49-73 baris, sedangkan untuk sisik bagian ventral berjumlah 221-324 baris. Sisik bagian keping anal bertipe single dan sisik ekor divided. Ular yang ditemukan termasuk masih anakan karena ukuran panjangnya yang masih pendek dan diameter tengah badan yang masih kecil. Ular kadut air ditemukan pada waktu malam hari pukul 18.11 WIB.

Ular M. reticulatus memiliki mata berwarna kuning dengan pupil vertikal, corak tubuh yang mencolok, pada tubuh ular memiliki pola warna hitam yang diselingi beberapa warna bercak cokelat gelap, abuabu dengan bercak putih. Kepala ular memiliki satu garis hitam di tengah memanjang yang membagi antara dua bagian kepala secara simetris hingga ke tengkuk dan masing-masing satu garis hitam tebal berada di tiap sisi kepala melewati mata ke belakang. Ular sawah batik memiliki pola lingkaran besar berbentuk jala, tersusun dari warna-warna hitam, kecokelatan, kuning, dan putih di sepanjang sisi dorsal tubuhnya. Sisik ular berwarna warni pada saat terkena sinar.

Ular M. reticulatus atau ular sawah atau juga biasa disebut ular sanca batik ini ditemukan di depan parkir Fakultas Kehutanan dekat parit yang tergenang air, diantara pohon-pohon, dan di parit dekat persimpangan arah ke Kampus MIPA. Mehrtens (1987), menyatakan bahwa ular phyton dapat ditemukan di habitat hutan tropis, hutan sekunder, areal berumput lebat, areal yang berdekatan dengan sungai besar, sungai kecil, maupun danau. Wardhani (2012), menyebutkan bahwa di Kalimantan Tengah, areal penangkapan ular phyton berada di kebun sawit, kebun karet, dan rawa-rawa. Ular ini aktif pada malam hari atau nokturnal. Namun terkadang juga dapat ditemukan pada pagi atau siang hari. Ular sawah sering ditemukan di area terestrial maupun arboreal. Ular sawah ini memangsa mamalia kecil, burung, dan reptilia lain. Ular sawah yang masih kecil sering memangsa kodok, kadal-kadalan, ikan, kemudian ular yang besar dapat memangsa anjing, monyet, babi hutan, rusa, bahkan manusia, dan ular sawah lebih memilih diam atau sembunyi menunggu mangsa (Mattison 1999, Murphy and Henderson 1997, Shinne et al., 1999).

Ular P. koros memiliki panjang total $1300 \mathrm{~mm}$, dengan panjang ekor $485 \mathrm{~mm}$, panjang kepala 30.10 $\mathrm{mm}$, lebar kepalanya $20.11 \mathrm{~mm}$, dengan jumlah sisik badan bagian dorsal 15 keping, ventral 171 keping, sisik labial berjumlah 8 baris, infra labial 10 baris, pre ocular dan post ocular 2 baris, mempunyai 1 sisik loreal, sisik dari ular ini halus (smooth), sisik ekor divided, keping anal devided. Ular ini ditemukan di tepi jalan raya sedang aktif bergerak mencari makan pada pukul 11.32 WIB atau pada pagi hari.

Tubuh ular P. korros didominasi oleh warna hitam kecokelatan di bagian dorsal, dan ventral didominasi oleh warna putih kekuningan. Ular $P$. Korros atau ular tikus memiliki bagian dorsal kepala berwarna cokelat kehitaman, mata bulat berwarna hitam, bagian ventral berwarna putih. Bagian badan dorsal berwarna cokelat kehitaman, 
bagian ventral kuning, ekor berwarna hitam (Das, 2016).

Ular P. korros sangat lincah saat bergerak mencari makan. Warna tubuh ular tikus ini memiliki warna cokelat pada bagian dorsal dan berwarna putih kekuningan di bagian ventral. Ular ini dapat dijumpai daerah terestrial seperti semak-semak, sekitar lingkungan manusia dekat perumahan, hutan, sawah dan kebun. Makanan dari ular ini berupa tikus, katak dan kadal. Ular ini termasuk ular yang tidak berbisa bagi manusia (Marlon, 2004).

Ular Ramphotyplops brasinus atau ular kawat ini memiliki tubuh yang sangat kecil, sekilas ular ini seperti seekor cacing tanah. Ular ini memiliki panjang tubuh sekitar 10-15 cm. Joger (2008), menemukan ular $R$. Brasinus dengan panjang total $92 \mathrm{~mm}$, dengan panjang ekor $2.5 \mathrm{~mm}$, dan diameter tubuh ular $1.6 \mathrm{~mm}$.

Tubuh ular berwarna hitam, kehitaman, kecoklatan, atau abu-abu kebiruan. Bagian kepala ular sangat sulit di bedakan dengan tubuhnya. Ekornya pendek dan ujungnya meruncing seperti duri. Tubuh ular memiliki sisik yang sangat kecil, halus, agak berkilauan dan tidak berlendir. Ular kawat ini memiliki mata yang sangat kecil. Selain bentuk tubuhnya, perilaku reptil dari famili Typhlopidae ini mirip cacing tanah. Ular ini bersembunyi di bawah batu, sampah, dalam tanah dan kayu-kayu busuk. Ular ini akan menggeliat seperti cacing jika merasa terganggu. Makanan dari ular kawat ini seperti hewan-hewan kecil, seperti semut, telur rayap, dan telur serangga lainnya. Ular kawat ini bukan termasuk ular yang berbisa ataupun berbahaya bagi manusia (Ridha, 2018).

Ular X. unicolor atau ular pelangi yang ditemukan memiliki panjang total $490 \mathrm{~mm}$, dengan panjang ekor 5,8 $\mathrm{mm}$. kepala ular pelangi memiliki panjang 19,47 mm, lebar kepala 10,98 mm. Kepala ular pelangi memiliki sisik supra labial dan infra labial berjumlah 8 keping, tidak mempunyai sisik loreal, sisik setengah badannya berjumlah 15 keping, kemudian sisik bagian ventral berjumlah 182 keping, pola bagian anal ekor ular divided, dan sisik ekornya divided.

Warna dari ular ini didominasi oleh warna hitam dan putih. Kepala bagian dorsal berwarna sedikit putih di bagian arah ke badan kemudian bercampur kehitaman. Mata ular bulat kecil berwarna hitam, bagian ventral kepala ular ini berwarna putih, di ujung mulut berwarna putih bercampur kehitaman.
Bagian badan ular berwarna cokelat untuk dorsal kemudian bagian ventral berwarna putih dan bagian ekor ular juga berwana cokelat bagian dorsal dan putih dibagian ventral adapun ujung ekor berwarna hitam. Ular ini sering mengeluarkan sinar berwarna warni ketika terkena bias cahaya, pola sisik dari ular ini licin lembut (Cox et al., 1998).

Ular X. unicolor atau ular pelangi merupakan ular yang aktif siang maupun malam hari. Ular ini ditemukan malam hari pada waktu pukul 22.12 WIB setelah hujan. Ular ini sering juga ditemukan pada waktu siang hari. Ular ini ditemukan sedang melakukan aktifitas bergerak dekat semak-semak menuju ke arah parit. Ketika di tangkap ular ini tidak melakukan perlawanan. Wogan (2012), menyebutkan bahwa ular dari X. unicolor atau ular pelangi ini mendiami kawasan rawa-rawa, semak belukar, daerah terganggu maupun tidak terganggu termasuk lingkungan perkotaan, sawah, area pertanian. Ular ini biasa sembunyi di daerah bebatuan, dekat air, menghabiskan waktunya didalam tanah, aktifitasnya pada malam hari, dan waktu hujan. Ular ini memakan amfibi, kadal, mammalia kecil dan burung yang tinggal di bawah tanah.

Ular A. prasina atau ular pucuk yang ditemukan di area pemukiman memiliki panjang total tubuh 990 $\mathrm{mm}$, memiliki panjang ekor $330 \mathrm{~mm}$, dengan panjang kepala $25.96 \mathrm{~mm}$. Sisik ventral memiliki 231 baris, sisik dorsal berjumlah 15 baris. Kepala bagian supra labial dan infralabial ular masingmasing berjumlah 9 baris, pre ocular 1, post ocular 2 , sisik loreal ada 2, sisik keping anal berpola divided.

Warna sisik A. prasina pada umumnya didominasi oleh warna hijau dari kepala hingga ujung ekornya. Hanya beberapa bagian yang memiliki warna tambahan seperti warna putih, dan warna kuning. Warna sisik kepala bagian dorsal hijau tua, ventral putih kehijauan, bagian labial berwarna hijau keputihan, dengan warna mata kuning dan pupil hitam horizontal. Badan ular bagian dorsal berwarna hijau daun sampai ke ujung ekor, ventralnya hijau kekuningan, ada garis kuning di bagian lateral, bagian ekor dorsal dan ventral berwarna hijau (Cox et al., 1998).

Ular A. prasina ditemukan pada waktu siang hari saat cuaca cerah, sedang beraktifitas mencari makan. Ular pucuk ditemukan di pohon kelapa dekat kampus FMIPA Universitas Tanjungpura 
Pontianak. Nurhayati (2018), menyebutkan bahwa ular A. prasinua atau ular pucuk merupakan ular yang memiliki tipe gigi ophistoglypha dan berbisa menengah namun tidak berbahaya bagi manusia. Kepala segitiga lancip, pupil bagian mata melintang dan bagian tubuh ular berwarna hijau. A. prasina hidupnya di pohon atau arboreal, namun tidak jarang juga ditemukan di atas tanah. Ular ini sering dijumpai di area pemukiman manusia, terutama di rumah warga yang memiliki banyak pohonpohonan yang memiliki daun-daun lebat berwarna hijau. Ular ini aktif pada siang hari atau diurnal untuk mencari makan. Ular $A$. prasina biasa memangsa serangga, burung-burung kecil dan katak (Marlon, 2004).

Ular D. pictus atau ular lidi merupakan ular yang ramping memiliki ekor yang hampir setengah badan dari badan ular. Ular lidi yang ditemukan ini memiliki panjang total $735 \mathrm{~mm}-990 \mathrm{~mm}$, dengan panjang ekor mencapai $220 \mathrm{~mm}-320 \mathrm{~mm}$. Ular lidi yang ditemukan ini memiliki panjang kepala 17.1128.33 lebar kepalanya $7.78 \mathrm{~mm}-15.10 \mathrm{~mm}$. Kepala ular lidi memiliki sisik supra labial 9 keping dan infra labial 10 keping, sisik bagian depan mata ular atau pre ocular-nya berjumlah 1 keping, sedangkan sisik post ocular berjumlah 2 keping dan memiliki 1 sisik loreal. Sisik setengah badan ular bagian dorsal berjumlah 15 keping, bagian ventral berjumlah 179 keping, sisik anal dan ekor berpola divided. Harikrishnan et al, (2007) menyebutkan bahwa ular Dendrelaphis pictus memiliki 177 baris sisik ventral, 15 baris sisik setengah lingkaran.

Ular lidi memiliki warna tubuh berwarna cokelat perunggu, di bagian dorsalnya. Sisik tubuh bagian bawah terdapat pita berwarna kuning terang keputihan, yang dipisahkan dari sisik ventral, kemudian ada garis hitam tipis memanjang hingga ke bagian ekor. Kepala ular lidi berwarna coklat bagian atasnya, bagian bibir ular berwarna kuning terang. Bagian dagu ular terdapat garis hitam mulai dari pipi melewati mata dan melebar di bagian pelipis belakang dan di bagian leher belakang. Leher ular terdapat warna-warna berupa bintikbintik hijau kebiruan di bagian leher hingga ke tubuh bagian muka. sisik berwarna kebiruan ini muncul ketika ular ini merasa terancam. Sisik badan bagian dorsal juga memiliki warna kecoklatan, terdapat garis hitam yang memisahkan antara sisik dorsal dan ventral. Warna sisik badan bagian ventral berwarna putih kekuningan, kehijauan sampai ke bagian ekor (Reza et al., 2016).
Ular D. pictus atau ular lidi ditemukan pada waktu siang hari di dekat tanaman bunga, di atas pohon, di dekat parit dan di dekat gedung perkuliahan. Persawahan merupakan tempat asli dari ular lidi yang dihuni oleh katak, kodok dan kadal (Wiguna et al., 2009). Ular D. pictus memiliki pergerakan yang lincah ketika keberadaannya diganggu. Ular lidi termasuk ular yang tidak berbisa bagi manusia, namun berbisa bagi ular lain (Putra, 2015).

Ular tedung atau $N$. sputatrix yang ditemukan memiliki panjang total $900 \mathrm{~mm}$, panjang ekor ular ini $105 \mathrm{~mm}$, panjang kepalanya 25,00 mm, memiliki jumlah supra labial 7 dan infra labial 9 keping, sisik pre ocolar 1 keping, sedangkan sisik post ocular berjumlah 3 keping, ular ini tidak memiliki sisik loreal. Ular tedung memiliki sisik setengah badan dengan jumlah 17 baris, sisik bagian ventral dari kepala sampai ke anal berjumlah 188 baris, sisik analnya divided, dan sisik ekornya single.

Ular N. sputatrix atau ular tedung memiliki warna tubuh yang didominasi warna hitam dan sedikit cokelat. Warna hitam terdapat di bagian dorsal kepala hingga ekor. Kemudian bagian ventral kepala sedikit berwarna cokelat dari ujung mulut sampai ke bagian leher selanjutnya warna hitam sampai ke ujung ekor. Ular ini memiliki pola sisik yang halus sedikit licin.

Ular tedung atau $N$. sputatrix merupakan ular yang mempunyai bisa yang mematikan bagi mangsanya maupun hewan lain yang mengangggu aktivitasnya. Ular $N$. sputatrix mempunyai taring bisa di rahang atas. Ahmad (2007), menyebutkan bahwa ular $N$. sputatrix ini memiliki bisa neurotoksin dengan tipe gigi proteroglypha yang terletak di bagian depan infralabia. Ular tedung di temukan di dalam rumah rusun belakang rumah sakit UNTAN yang berdekatan dengan perkebunan singkong. Parjoni (2012), menemukan ular Naja sputatrix di kawasan seperti sawah, daerah ekoton, kebun masyarakat, hutan jati, pemukiman dan rel kereta api. Ular tedung merupakan hewan yang aktif mencari makan pada waktu malam hari, namun terkadang juga dapat aktif waktu siang hari.

Berdasarkan hasil penelitian yang telah dilakukan, ular yang banyak ditemukan yaitu ular D. pictus yang berjumlah empat ekor. Wiguna et al. (2009) menyebutkan bahwa spesies ular D. pictus banyak ditemukan karena habitat persawahan merupakan habitat asli dari ular, yang dihuni oleh kodok, katak, dan kadal. Ular D. pictus merupakan spesies ular yang umum ditemukan pada habitat dengan kondisi lingkungan terganggu atau dekat dengan manusia 
(Stuebing dan Inger 1999). Faktor lain yang menyebabkan banyaknya ular $D$. pictus yang ditemukan adalah kurangnya predator alami yang terdapat di sekitar area penelitian. Putra (2015), menyebutkan bahwa ular $D$. pictus ini tidak dimangsa oleh ular kanibal.

Ular yang paling sedikit ditemukan yaitu Ahaetulla prasinus, Coelognathus flavolineatus, Ptyas korros, Naja sputatrix, Homalopsis buccata, Ramphotyphlops braminus dan Xenopeltis unicolor masing-masing satu ekor. Reza (2016), menyebutkan bahwa tersedianya makanan, habitat serta suhu dan kelembaban yang mendukung, memungkinkan bagi ular untuk hidup dan menetap di suatu tempat. Sedikitnya ular yang ditemukan di atas dapat dilihat dari faktor makanan, makanan yang dimakan oleh ular di atas hampir sama seperti ular C. flavolineatus, M. reticulatus, $N$. sputarix dan ular $P$. Korros sama- sama memakan hewan pengerat seperti tikus. Ular lain seperti ular $D$. pictus, $P$. Korros, M. reticulatus yang masih kecil, $H$. buccata dan $X$. unicolor memakan katak dan kodok. Ular $A$. prasina merupakan ular yang sebagian besar hidupnya di pohon dan berlindung di antara dedaunan membuat ular ini sulit ditemukan karena ular R. Brasinus berada di dalam tanah. Ular $R$. brasinus sangat jarang keluar dari dalam tanah. Faktor lain yang menyebabkan sedikitnya individu ular yang ditemukan adalah kemungkinan adanya perburuan ular dan kurangnya pengetahuan masyarakat terhadap peran ular dalam ekosistem, sehingga jika ada masyarakat menemukan ular maka ular tersebut ditangkap untuk dijual, dan di bunuh karena merasa berbahaya bagi nyawa manusia (Asri, 2015).

Ular yang ditemukan di Kawasan Kampus UNTAN terdiri atas 3 Habitat seperti di air, tanah, dan di pohon. Ular yang paling banyak ditemukan sebagian besar ular yang hidupnya di terestrial (permukaan tanah, serasah, rerumputan) berjumlah 7 jenis, sedangkan ular yang ditemukan di pohon hanya satu jenis dan ular semi akuatik (di parit, genangan air) sebanyak dua jenis. Kawasan penelitian ular ini terdapat di sekitar kampus UNTAN Pontianak yang terdapat banyak gedung perkuliahan, terdapat banyak perumahan warga dan mess mahasiswa. Aktivitas sehari-hari di kawasan UNTAN juga terdapat pembukaan lahan kebun sayur-sayuran, padi, sawit dan pemeliharaan hewan.

Famili dari Colubridae adalah famili yang paling banyak ditemukan di sekitar kawasan Kampus UNTAN Pontianak. Famili ini terdiri dari 4 spesies yaitu Ahaetulla prasinus, Coelognathus Flavolineatus, Dendrelaphis pictus, dan Ptyas korros. Purbatrapsila (2009), menemukan ular dari famili Colubridae sebanyak 11 genus di Taman Nasional Tanjung Puting Kalimantan Tengah,. sedangkan Stuebing dan Inger (1999), menyebutkan bahwa ular Colubridae adalah suku ular paling banyak jumlah jenis yang ditemukan di Kalimantan. Suku Colubridae memiliki sebaran paling luas, dan terdapat pada berbagai tipe habitat (Goin et al., 1978). Famili yang sedikit ditemukan yaitu: Cylindrophiidae, Elapidae, Homalopsidae, Pythonidae, Typlopidae, Xenopeltidae yang terdiri dari masing-masing satu jenis.

Suhu udara di kawasan kampus UNTAN Pontianak pada waktu penelitian selama satu bulan mulai dari bulan April-Mei 2018 berkisar $25-33^{\circ} \mathrm{C}$ pada pagi hari, sedangkan pada malam hari suhu udara berkisar $24-29^{\circ} \mathrm{C}$. Suhu tersebut masih dapat ditoleransi oleh ular. Hirth (1969), menyebutkan bahwa suhu tubuh yang disukai oleh sebagian besar ular berkisar antara $28-34^{\circ} \mathrm{C}$, jika di atas $36^{\circ} \mathrm{C}$ ular akan mencari tempat teduh. Sedangkan kelembaban di kawasan kampus UNTAN Pontianak pada waktu penelitian berkisar $27-46 \%$ pada pagi hari dan berkisar $25-45 \%$ pada malam hari. Kelembaban di kawasan UNTAN Pontianak sangat rendah. Menurut Nurhayati (2018), menyebutkan bahwa kelembaban udara yang rendah menambah faktor ular jarang ditemukan. Sedangkan penelitian Silalahi (2015) menemukan ular pada kelembaban berkisar antara 68-72\%, sehingga ular yang ditemukan di kawasan UNTAN Pontianak masih terbilang kurang.

\section{DAFTAR PUSTAKA}

Abouheif E, dan Fairbairn DJ. 1997. A comparative analysis of allometry for sexual zise dimorphism: assessing rensch' rule. The American Naturalist 149:

Ahmad R. 2007. Mengenal Ular-Ular Berbisa. Pusat Racun Negara. Malaysia

Amarsinghe, A.A.T., Campbell, P.D., Hallerman, J., Sidik, I., Supriatna, J., Ineich, I. (2015): Two new spesies of the genus Cylindrophis Wagler, 1928 (Squamata: Cylindrophiidae) from Southeast Asia. Amphibian \& Reptile Concervation 9: 34-51.

Asad S., Jimi L. M., dan Agus P. P. 2012. The Herpetofauna of Nusa Penida, Indonesia. Herpetologycal Bulletin; Issue Number: 122. 
Das, A. 2016. Addition to the Herpetofauna of Royal Manas National Park, Bhutan, with six new new country records. Herpetology Notes 9:261-278

Forey, P., dan Fitzsimons, C. 1987. Instant Guide to Reptiles and Bungarus Candidus. Journal of Medical Association Thai. 90 (7): 1467-76

Goin CJ, Goin OB, Zug ZR. 1978. Introduction to Herpetology. Third Edition. San Fransisco: $W$. H. Freeman and Company.

Grismer, L.L., Thy, N., Thou, C. and Grismer, J. L. 2008. Checklist of the amphibians and reptiles of the Cardamon region of southwestern Cambodja. Cambodian Journal of Natural History 2008 (1):12-28.

Harikrishman, S, Deepak V, and Vasudevan K. 2007. Report Of Painted Bronze-Back Tree Snake Dendrelaphis pictus Gmelin, 1789 From Anamalais, Western Ghats, India. Zoos Print Journal. 22 (12):2929

Gunawan, H. dan L.B. Prasetyo. 2013. Fragmentasi Hutan :Teori yang mendasari penataan ruang hutan menuju pembangunanberkelanjutan. Pusat Peneli tian dan Pengembangan Konservasi dan Rehabilitasi. Bogor.

Hikman CP, Roberts LS, Larson A. 2001. Integrated Principles of Zoology.Volume to-11. The McGraw-Hill Companies, Inc. New York.

Hirth H. F., King A. C., 1969. Body temperatures of snake in different seasons.

Inger, R.F., 1966. The Systematics and Zoogeography of The Amfibia of Borneo, Field Museum of Nature History, Chicago.

Inger and Voris, H.K., 2006. Assessment of Biodiversity among Southeast Asian Amphibian and Reptiles, Nat. Hist. J. Chulalongkorn. Univ., 6:1-10

Joger U, Bshena I and Essghaier 2008. First Record of the Parthenogenetic Brahminy Blind Snake, Ramphotyphlops braminus (Daundin, 1803), From Libya (Serpentes: Typhlopidae). Herpetelogy Notes, Volume 1:13-16

Krey, K, 2008. Daerah Penyebaran dan Variasi Morfologi Ular Putih (Micropechis ikaheka) di Papua, Tesis, Institut Pertanian Bogor, Bogor.

Kusrini, M. D, 2008, Pedoman Penelitian dan Survei Amfibi di Alam, Pustaka Media Konservasi, Bogor, 154 hal.
Marlon, R. 2014. Panduan Visual dan Identifikasi Lapangan: 107+ Ular Indonesia Printer.

Mattison C. 1999. Snake. New York, NY: DK publishing, Inc.

Mattison C. 2005. Encyclopedia of Reptiles and Amphibians, an Essential Guide to Reptiles and Amphibians of the World.Singapore: Grange Books Plc.

Mattison C. 2014. Nature Guide: Snake and Other Reptiles and Amphibians. Hudson Street, New york: Dorling Kindersley Publishing.

Mehrtens, J.M. (1987). Living snakes of the world; in colour. NewYork: Sterling Publishing Co.

Murphy J and Henderson R. 1997. Tales of Giant Snakes. Fl: Krieger publishing company. Malabar.

O'Shea, M, Fred Parker, and Hindrich, K, 2015. A New Species of New Guinea Worm-Eating Snake, Genus Toxicocalamus (Serpentes: Elapidae), From The Star Mountains of Western Province, Papua New Guinea, With a Revise Dichotomous Key To The Genus. Museum Of Comparative Zoology, Vol. 161, (6):241-264.

Parjoni. 2012. Tata Niaga, Parameter Demografi dan Karakteristik Habitat Ular Sendok Naja Sputatrix (Boie. 1827) di Provinsi Jawa Timur [Tesis]. Bogor(ID): Sekolah Pascasarjana Institut Pertanian Bogor.

Purbatrasila A, 2009. Studi Keanekaragaman Jenis dan Sebaran Spasial Ular pada Beberapa Tipe Habitat di Taman Nasional Tanjung Puting, Kalimantan Tengah, Skripsi, Institut Pertanian Bogor, Bogor.

Putra, I. G.A. P. 2015. Spesies-spesies Ular (Serpenthes) yang ditemukan Di Desa Singapadu, Kabupaten Gianyar, Bali (Tesis). Denpasar. Universitas Udayana. Bali

Reza F., Tjong. D. H., \& Novarino, W. 2016. Karakteristik Morfologi Ular Familia Elapidae di Kampus Universitas Andalas Limau Manih Padang. Jurnal of sainstek 8 (2): 135- 141

Rooij ND, 1917. The Reptiles of the Indo-Australian Archipelago. Volume ke-2, Ophidia. Leiden: E. J. Brill Ltd.

Shine R. 1981. Venomous snakes in cold climates: ecology of the Australian genus Drysdalia 
(serpentes: Elapidae). American Society of Ichthyologistsand Herpetologists 14-25.

Shine R, Ambariyanto, Harlow PS, Mumpuni. 1999. Reticulated python in Sumatra, harvesting and sustainability. J. Biologycal Conservation, 87:349-357

Soehartono $\mathrm{T}$ dan Mardiastuti, 2003. Pelaksanan Konvensi CITES di Indonesia. Jakarta. Japan International Cooperation Agency (JICA).

Stafford, P. J. 1986. Pythons and Boas. T.F.H. Publications, Inc., New Jersey, USA.

Stuebing, R.B., R.F. Inger. 1999. A Fied Guide to the Snake of Borneo. Natural History Publication (Borneo). Kota Kinabalu.

Sutherland JW. 2000. The Conservation Handbook Research, Management and Policy. Blackwell Science Ltd. USA.

Taylor B, O'Shea M. 2004. The Great Big Book of Snakes \& Reptiles. Anness Publishing Ltd Hermes House, 88-89 Blackfriars Road. London.

Utiger U, Schatt B and Helfenberger N, 2005. The Oriental Colubrine Genus Coelognathus Fitzinger, 1843 and Clasifikasion of Old and New World Races and Ratsnakes (Reptilia, Squamata, Colubridae, Colubrinae). Russian Journal Of Herpetology. Vol. 12, No. 1

Wardhani, S. E. (2012). Tata Niaga, Karakteristik Habitat dan Parameter Demografi Sanca Batik (Phyton reticulatus Schneider 1801) yang di panen di Provinsi Kalimantan Tengah. (Tesis). Program Pascasarjana. Institut Pertanian Bogor, Bogor.

Wiguna C., Dharmono \& Kapsul, 2009. Inventarisasi Spesies Ular di Desa Keliling Benteng Ilir Kecamatan Sungai Tabuk Kabupaten Banjar. Jurnal Wahana-Bio 1 (1):33-41.

Wogan, G., Vogel, G., Nguyen, T.Q.\& Thy, N. 2012. Xenopeltis unicolor. The IUCN Red list of Threatened Species 2012: e T17841A1536060.

Zug, George R. 1993. Herpetology an Introductory Biology of Ampibians and Reptiles. Academic Press, London, p: $357-358$. 